\title{
Sociological Impact of the Closure of Prostitution Business in Kedung Banteng to the Prostitute's Social Life
}

\author{
Dian Suluh Kusuma Dewi \\ Universitas Muhammadiyah Ponorogo \\ Ponorogo, Indonesia \\ suluh.dian@gmail.com
}

\author{
Slamet Santoso \\ Universitas Muhammadiyah Ponorogo \\ Ponorogo, Indonesia
}

\begin{abstract}
East Java free from prostitution has become the turning point that makes regional government of Ponorogo Regency intends to close any form of prostitution. In June 2015, Kedung Banteng, the only one prostitution business in Ponorogo, was officially closed down by The Minister of Social, Khofifah Indar Parawangsa. This closure then is followed by the demolition of its buildings in April 2016. In the context of freeing Ponorogo from any prostitution business, the government have already done their work well. The outcome expected from this study is an article published in an accredited national journal and a supporting teaching material that is significantly used in Public Policy Analysis subject and Sociology subject. Unfortunately, these coffee shops not only offer cups of coffee or food, but also provide hidden prostitution business. In this case, the sexual transaction is done online using some social media applications such as Blackberry messenger and Whatsapp application, while the prostitution action took place in a hotel and in a lodging house using short time system.
\end{abstract}

Keywords - social impact; prostitution; social life

\section{INTRODUCTION}

In 2014, the closing down of prostitution localization in some areas in East Java Province which includes the regional government has met its success. For instance, a big wellknown prostitution localization named Dolly along with another 46 spots was successfully closed down by regional government, including the recent one, prostitution localization in Kedung Banteng, Sukorejo sub district, Ponorogo.

The process is officially led by the regional government of East Java which is represented by Social Minister Khofofah Indar Parawangsa on $8^{\text {th }}$ of June 2015. Then it was continued respectively by Regent of Ponorogo, Ipong Muchlison, on $11^{\text {th }}$ of April 2016.

The world of prostitution actually has been categorized as the black world of society that needs to be solved. In the fact, closing down the prostitution spots, especially in Kedung Banteng done by the regional government of East Java province may not be the best solution. In a discussion forum of local community initiated by Social Department, Prof. Dr. Hotman Siahaan, a sociologist from Airlangga University, stated that the closure process of prostitution spots actually do not solve the problem. Instead, it leads to other problems since the concern of prostitution is not solely resulted from one particular factor, economic for instance. Even in welldeveloped countries, the prostitution business is there.

Concerning the phenomenon, the process closing down of prostitution spots done by regional government of East Java Province continued by regional government in Ponorogo can be observed from two approaches. Firstly, it can be analyzed from the aspect of public policy and its implementation, and secondly, it can be analyzed from the aspect of sociology of the ex-prostitutes.

In the approach of public policy analysis, public policy is considered as strict decision bending people altogether to a strategic level of general rules issued by the decision makers of public authority. As a people-binding decision, what is ruled as public policy then should be specifically proposed only by people having politic authority, those who are having public credential from the process of general election. Then, that public policy is managed by government officers as part of state's bureaucracy. In term of public policy, the main focus to be concerned is the public services. It refers to any single thing state can give to maintain and develop the quality of life of its citizens. In this case, many things need to be concerned and balanced well. For instance, balancing the role of the country as a public services provider and its right to take tax and retribution, and balancing the rights of citizens from various backgrounds with their different concerns and the constitutional mandate. 
In the case of Kedung Banteng prostitution spot, the country which is represented by the regional government of East Java province and Ponorogo regency has done their works well. However, this result also has led to a new problem in term of social issues and the impacts for the prostitutes.

From the society impact point of view, this condition is terrible because in fact, the prostitution business is not completely closed down. The prostitutes still try to find another place to run their business secretly. In this case, illegal prostitution then becomes their decisions.

\section{RESEARCH METHOD}

This research is a descriptive qualitative research since it aims to get brief description that is naturally and comprehensively described concerning the sociological effect after the Prostitution business spot in Kedung Banteng is closed down towards the prostitutes' life. It is stated that qualitative methodology is a research procedure that produce descriptive data in form of written words or spoken utterance from the subject being observed. Simply, this research is a qualitative research since it does not include the statistic in it [1].

The setting of this research is decided based on prior assumption concerning alternative places might be chosen by ex-prostitutes to continue their life after their business was closed down. It was found that there are three available spots; in Siman, Balong, Danyang, and in the surrounding of integrated offices of Ponorogo regional government.

Then, the informants are decided using purposive sampling and snowball sampling. Purposive sampling is a sampling technique used to collect the data based on certain judgments or purposes. For example, the data is taken based on consideration towards what someone knows or on what position he is. Having policy maker as a subject research is good since it eased the researcher to observe thoroughly the phenomena being studied. In other words, the data is taken based on researcher's necessity.

In the other hands, snowball sampling is a sampling technique used to collect the data by enlarging or raising the amount of informants involved in the research significantly based on the necessity of data completion, so that the data being collected is complete and comprehensive [2].

In this study, the researcher used in-depth interview as the technique of collecting the data. The interview is not in form of closed, structured and formal interview. Instead it is an opened, semi-structured and informal interview. It is done to maintain the trustworthiness of the original information given by the subject without giving certain pressure.

\section{RESULT FINDINGS AND DISCUSSION}

According to Governor's Instruction number 460/16474/031/2010 concerning the handling and tackling process of prostitution and woman trafficking and Instruction of the Government number 460/15612/031/2011 concerning the tackling of prostitution business in East Java province, there are several important points stated there.

They are: Closing down the prostitution business spots and others places around citizens' surrounding area that is suspected as illegal business place without relocating the prostitutes. It is done by involving all elements of society such as religious leaders [3], society's public figure, Family Welfare Program, and other Social and Welfare Departments and by coordinating with the head of the country police or District Military Command before the end of 2014.

Changing the value, attitude, and behaviour had by the prostitutes and ex-prostitutes through the activities of spiritual development, training of skills before and after staying in the hometown, and acceleration process of functional shift of exprostitution spots to become new economic business centre or other public services places.

Develop harmonic cooperation among regional areas in tackling the prostitution business, particularly the main area of prostitution spots (where the prostitutes run their business) as well as the hometown of the prostitutes (where they come from) and develop alternative employment by prioritizing the poverty tackling in the hometown of the prostitutes.

To support the tackling process and post-closure process of the prostitution spots, it is expected that each Regent or major of City to issue its Instruction of Government or Local Government regulation that provides solution and guarantee of law-related matter concerning the tackling and closing of prostitution business spot in local areas. The governor's instruction along side with the items is the basic principle that must be done and accomplished during while-closure or postclosure process.

Based on that instruction, Regent of Ponorogo then issued Regent's Regulation as the follow up activity. The result is the Regent Regulation number 1 year 2015 stating about the closure of prostitution business spot in Keding Banteng village, Sukorejo sub district, Ponorogo Regency is issued.

That is why the regional Department of Social, Manpower, and Transmigration of Ponorogo respectively responded to the instruction by closing down the prostitution spot in Kedung Banteng. Generally speaking, the closure process of the prostitution spots is accomplished within three stages. They are: Stage of Data Identification, Stage of Socialisation and Coordination, Stage of Empowerment, Stage of Repatriation Declaration, Stage of Emptying the Business 
Spot. To know the condition in this area after the closure process, monitoring and evaluation process are things need to be done after all. These activities are done to decide what proper actions that are possibly done to make use of the area to be more valuable[4].

In fact, there are still some problems remaining there. One of them is concerning the local government readiness in resolving the side effects, including the social and economic effects of post-closure process in which the negative impacts are still much bigger rather than the positive ones. Theoretically, this closure process is significant for most of Ponorogo citizens since one of big entrance to negative attitudes in society is permanently closed. However, the result may be far beyond expectation. It is proved by the absence of significant follow up activities provided by the associated department and governmental institutions only for the exprostitutes and other parties impacted from this closure. They only monitor the situation without doing the real action of supervision. They argued that this condition is happening because there is no exact rule from the regional government concerning this policy.

The worst impact from certain circumstance is that the ex-prostitutes have to sell all their stuffs, literally meaning everything they have, so that they can survive, while some prefer to leave their hometown to work abroad as labors. Actually they already got some life skill trainings, such as training of being crackers maker. However, they could not make use of it comprehensively. It seems that they do not have intention to use that skill as their financial source.

They claimed that the training they got is less than enough to make them comprehend the ability.From the social aspect, many ex-prostitutes argued that they cannot apply the skill they got from the training program given before as their occupation because they found it difficult to handle the market or to sell the products. As the result, they could not earn enough money to fulfill their daily needs. As the result, many illegal prostitution businesses appear in which it is secretly covered in the business of traditional coffee shops. Some traditional coffee shop stores in Siman, Balong, Danyang and around the Integrated Service Office are those assumed as illegal prostitution business as they provide spot for prostitution transaction. Even the owners allow their customers to bring the prostitutes to the hotel to avoid the citizens' suspicion.

\section{CONCLUSION}

Even though, the process of closing down the prostitution business in Kedung Banteng is basically successfully done by the regional government of Ponorogo Regency in associated with the province government, the effect of this closure towards the prostitutes' life got bigger. The biggest effect is concerning economic aspect that is still unfinished until now. The compensation fund given by the government is not enough to sustain their lives for long time and the result of skill training given by Department of Social, Manpower and Transmigration cannot be comprehensively, maximally applied. Thus, many of the ex-prostitutes have to sell all their stuffs only for prolong and sustain their lives.

\section{REFERENCES}

[1] Moleong, Lexy J. 2012. Metodologi Penelitian Kualitatif. Remaja Rosdakarya; Bandung.

[2] Hadari Nawawi, Metode Analisis Data Kualitatif. Jakarta : Kencana, 1987

[3] Idrus, Muhammad, Metode Penelitian Ilmu Sosial. Yogyakarta : PT. Gelora Aksara Pratama, 2009

[4] Winarno, Budi. 2012. Kebijakan Publik Teori, Proses, dan Studi Kasus. Yogyakarta: CAPS 